\title{
Floral Biology of Cacauhy (Theobroma Malvaceae)
}

\author{
Márcio Silva de Souza ${ }^{1}$ and Giorgini Augusto Venturieri ${ }^{2 *}$ \\ ${ }^{1}$ Laboratório de Ecologia do Fitoplâncton e Microorganismos Marinhos; Departamento de Oceanografia; \\ Fundação Universidade Federal do Rio Grande; C. P: 96201-900; Rio Grande - RS - Brasil. ${ }^{2}$ Laboratório de \\ Evolução Aplicada; Centro de Ciências Biológicas; Universidade Federal de Santa Catarina; C P.: 88.040-900; \\ Florianópolis - SC - Brasil
}

\begin{abstract}
In the present work, cacauhy's (Theobroma speciosum) floral biology was studied. Flower buds split their sepals at $14 \mathrm{~h}$ reaching its maximum at $22 \mathrm{~h}$, but all flowers were fully opened at 6:00 $\mathrm{h}$ of the following morning. Stigmatic branches showed exudates, reaching maximum between 6:00 $\mathrm{h}$ and 10:00 $\mathrm{h}$ at the same day. Ligules and petal hoods were the floral parts with highest intensity of odour. Flowers were receptive along all the morning and noon of the anthesis day. Approximately $65 \%$ of the flowers were naturally pollinated, but only $0.85 \%$ of them set a fruit. Abscission occurred on its higher frequency at 6:00 h of the second day after anthesis. Controlled pollinations showed that cacauhy was self-incompatible species.
\end{abstract}

Key words: self-incompatibility, flower behavior, hybridization, cocoa

\section{INTRODUCTION}

The Theobroma genus has 22 species and eight are Amazonian trees. It has an economic importance both in the past and in the present. In the past, there was cacau-do-Peru (Theobroma bicolor), a preColumbian crop which seeds were eaten toasted and considered a delicacy (FAO, 1986). At the present, there is cocoa (T. cacao) used in the food industry of chocolate and the cupuassu ( $T$. grandiflorum) considered one of the most profitable crops of Amazonia, whose pulp has been used to prepare juices, ice-creams and sweets (Venturieri, 1993). Although cacauhy (T. speciosum) is considered an economically inexpressive species, it is close genetically to cocoa (T. cacao) and cupuassu ( $T$. grandiflorum) and so a possible font of genes for them. It is also known as "cacauí (at Brazil); "cacaoy", "cacaoíllo", "cacau-rana", "cacao biaro", "cupuyh", "cacao sacha" (at Peru), or "chocolatillo" (at Bolivia). Although its use is not popular at Amazonia, its pulp is consumed fresh and from its seeds, a chocolate can be prepared, considered as low quality by Cuatrecasas (1964), an opinion that is not shared by Le Cointe (1934) that considered it excellent.

Cacauhy is a median tree that reaches up to $15 \mathrm{~m}$ in height with a straight trunk and a small canopy. Leaves are coreaceous, distichous, with limb ovateoblong or elliptic-oblong, with the base subrounded, asymmetric, with $20-40 \mathrm{~cm}$ in height and $7-18 \mathrm{~cm}$ in width, with 8 pairs of lateral nerves strongly inclined for the apex. Flowers are born in the majority in dense cushions in the trunk and have

*Author for correspondence: giorgini@ccb.ufsc.br 
a strong odour of lemon skin (Fig. 1a); flower buds, sepals, petals (except cogules) and staminodes are dark red; staminodes are in 5, subulate and alternated with stamens (Fig. 1b); fruits are roundellipsoid, with around $10 \mathrm{~cm}$ in length slightly pentagon and sulcated, the skin is slightly velveted and yellow on the ripe fruit; each fruit has around
20 seeds surrounded by a white pulp, almost without odour (Cavalcante, 1988). The cacauhy is the Theobroma species with wider distribution, occurring in all the Amazonian Hylea and from it up to South of Central America (Ducke, 1953), exceeding the limits of the Hylean flora at the state of Maranhão (Cuatrecasas, 1964).
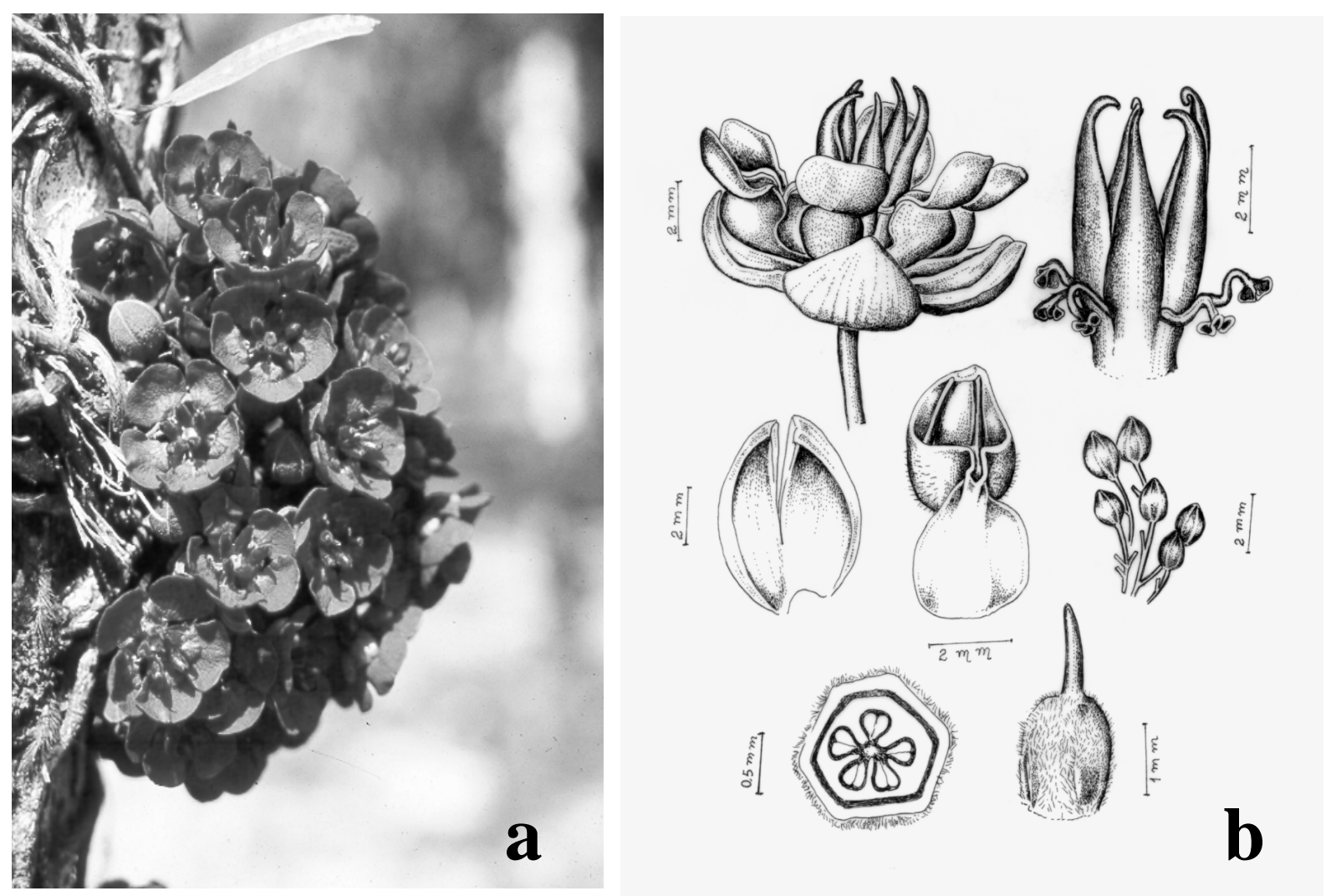

Figure 1 - The cacauhy (Theobroma speciosum): a) flower cushion (photo from G.A. Venturieri); b) flower details (drawn from Antônio Elielson S. da Rocha).

Hybridisation of cocoa (T. cacao) with other close species has been suggested as a strategy to improve the resistance against "swollen shoot" (Martinson, 1972) and "witch's broom disease" (Addison and Tavares, 1952). The first is a virus responsible for serious damages in the cocoa production in Western Africa; the second is caused by a fungus, responsible for significant depletion in the cocoa production in Brazil. Addison and Tavares, (1952) tried to hybridise the Amazonian species of Theobroma but without knowledge about the breeding system and floral biology of the majority of the involved species. Apparently it had limited the hybridization success between cocoa and its relative species such as cacauhy ( $T$. speciosum). The temporal patterns of flower development of $T$. cacao, T. speciosum, T. mammosum and Herrania cuatrecasana were studied by Young et al. (1987), but generated data were scarce.

In the present work, was described the floral behaviour of caucauhy (T. speciosum), its pattern of pollen deposition on the stigmatic branches and the species' breeding system. Also, by indirect methods, the period of receptivity of the stigmatic branches was assessed. 


\section{MATERIALS AND METHODS}

The study was carried out between August and September of 1995 using a living collection of the Theobroma species "George Basil Bartley", at the Estação Experimental de Recursos Genéticos do Cacau "José Aroldo" - ERJOH in Marituba (located at Km 17 of the BR 316 highway; Lat. 1 $12^{\prime} \mathrm{S}$; Long. $49^{\circ} 13^{\prime} \mathrm{W}$ ) and belonged to the Comissão Executiva do Plano da Lavoura Cacaueira (CEPLAC), and, during July of 1996, at the Empresa Brasileira de Pesquisa Agropecuária Amazônia Oriental (EMBRAPA - Amazônia Oriental) in Belém (Lat. $1^{\circ} 20^{\prime} \mathrm{S}$; Long. $48^{\circ} 30^{\prime} \mathrm{W}$ ). Both sites are in the state of Pará, in the North of Brazil. The plants studied were growing in an Oxisol with red and yellow argilites and a low drainage capacity (Neves and Barbosa, 1983). According to Köppen's classification, these sites have an "Afi" climate (mean temperature of $26^{\circ} \mathrm{C}$, air humidity $84 \%$ and mean annual rainfall 2,600 $\mathrm{mm}$ ) (Salati, 1985). The identification codes of the plants studied at ERJOH were: 6L-07, 6L-11, 6L13, 6L-16 and 8L-8; and at EMBRAPA Amazônia Oriental, seven plants were studied, identified as A, B, C, D, E, F and G, all labelled in the field with aluminium tags nailed to their trunks.

A total of 244 flower buds were labelled close to the anthesis point in order to allow the daily blooming pattern of the trees at CEPLAC and EMBRAPA - Amazônia Oriental to be determined. Observations were made at 6:00, 10:00, 14:00, 18:00 and 22:00 h, for four consecutive days. The times of pre-anthesis (the point at which flowers began to split their sepals); anthesis (when petals were fully open and staminodes had diverged so that the pistil could be seen) and abscission (when flowers had fallen spontaneously or fell after a light touch) were recorded. Flower longevity was defined as the time between anthesis and abscission and recorded. During the first two days after anthesis, representative schematic drawings were made of the position of floral whorls (staminodes, ligules, cogules and sepals) at each time of observation. The most frequently occurring type (the mode) was used to indicate the phase. During the same period, the colours of the petals (ligules + cogules), sepals and staminodes of a single plant considered representative of the group were recorded. The colours were compared and named according to a colour chart of Kornerup and Wanscher (1984).

At 10:00 h, every day for six days, six flowers were collected on their day of anthesis from plants 6L-07,
6L-11, 6L-13 and 6L-16. These were immediately dissected and their parts grouped into three classes: 1) ligules and cogules; 2) staminodes and stamens; and 3) sepals, ovaries and peduncles. Samples of each class of flower parts were placed in a stoppered vial for one hour and then smelled by three different persons. Each person attributed a subjective grade from 1 to 3 ( $1=$ odour barely perceptible; $2=$ odour moderately perceptible; $3=$ intense odour immediately perceptible). They did not exchange opinions about the assay during the experiment. Six groups of flowers were collected, and three flower part classes were compared by three observers who attributed one of three different grades to each, so their grades were compared using a $\chi^{2}$ contingency test for $\mathrm{N}=162(6 \times 3 \times 3 \times 3)$.

For three consecutive days, flowers were collected at 6:00, 10:00, 14:00, 18:00 and 22:00 h, which corresponded to the time of anthesis plus 4,8 and $12 \mathrm{~h}$, and so on until $56 \mathrm{~h}$ after anthesis beginning. The quantity of exudate on these flowers stigmatic branches was observed using a stereomicroscope and classified subjectively. Depending to the quantity of exudate observed, grades were attributed as follows: $0=$ without visible exudate; 1 $=$ exudate covering all the stigmatic branches as a thin layer; 2 = exudate forming a hemispherical droplet; and $3=$ a copious quantity of exudate, forming a spherical droplet.

Flower receptivity was assessed indirectly by means of stigmatic reaction of Peroxidase with a $0.3 \%$ solution of Peridrol (containing $30 \%$ of $\mathrm{H}_{2} \mathrm{O}_{2}$ ). On the first, the second and the third days after anthesis beginning, six flowers were collected each time, at 6:00, 10:00, 14:00, 18:00 and 22:00 h. These flowers were taken to the laboratory where their pistils were removed and placed on a Petri dish. A drop of $\mathrm{H}_{2} \mathrm{O}_{2}$ solution was carefully deposited on the stigmatic branches only. As the $\mathrm{H}_{2} \mathrm{O}_{2}$ reacted with the Peroxidase, free $\mathrm{O}_{2}$ bubbles were formed in the solution. These bubbles were used to evaluate the Peroxidase reaction level (Zeisler, 1938). After approximately five seconds, the reaction of each pistil was subjectively classified as: weak $=$ with emission of up to 5 bubbles/second; intermediate = with emission of 6 to 15 bubbles/second; or strong $=$ with emission of more than 15 bubbles/second.

The natural pollination level was evaluated in all the flowers selected and identified for the behaviour studies. The flowers were collected after they had fallen naturally or were taken on the fourth day after anthesis, then were placed in plastic bags and transported to the laboratory, taking care to avoid 
the accidental pollination during the transport. The stigmatic branches of each flower were taken off at the base and put on slides and then three drops of an aqueous solution of Cotton Blue at $0.01 \%$ were added and a coverslip put in place. Slight pressure was then applied to open the stigmatic branches. The dye was applied in order to stain the pollen exine and make the pollen grains more visible while they were being counted. Each stigmatic branch was visually divided into three parts (basal, median and apical) and the pollen grains on each were counted up to a maximum of 60 grains. Branches with more grains than this were classified as having "more than 60 pollen grains". Pearson's correlation coefficient $(r)$ was calculated for the relationship between the length of time flowers remained on the plant and the number of pollen grains deposited on their stigmatic branches.

In order to study the occurrence of possible incompatibilities within and between plants (the breeding system), flowers from three plants at CEPLAC were self- and cross-pollinated. Pollinations were carried out according to the method described by Venturieri and Ribeiro (1995), from 9 to 12 of November of 1996. Fifteen flowers were pollinated per match. The same number of flowers were marked, and left to be pollinated naturally to serve as a control. The pollinated and marked flowers were visited at 3-day intervals up to the 9th day after pollination and again when ripe (60th day after pollination). The number of fruits was recorded during these visits. Where fruits had aborted, they were observed to check whether this was due to natural damage or to a possible late effect of incompatibility.

Pollen tube growth was recorded in the flowers pollinated with either compatible or incompatible pollen grains (and where incompatible, the site of incompatibility) from crosses between five plants (6L-7; 6L-9; 6L-11; 6L-13 and 6L-16) from CEPLAC that were matched when possible, and of which three were self-pollinated and six crosspollinated. Pollination was performed at 7:00 to 8:30; 10:00 to $11: 30$ and 14:00 to $15: 30 \mathrm{~h}$. The same procedures were also carried out with three plants from EMBRAPA - Amazônia Oriental, but these were only pollinated between 7:00 and 8:30 h. All flowers were collected $24 \mathrm{~h}$ after pollination and fixed in FAA (Radford et al., 1974). The pistils were stained with 1 part of $0.1 \%$ methyl blue in $1 \mathrm{~N}$ $\mathrm{K}_{3} \mathrm{PO}_{4}$ (Kho and Baer, 1986) and observed by microscope under UV light. The stigmatic branches were then mounted in $90 \%$ glycerol and squashed gently. Stigmatic branches were examined using a UV microscope (ZEISS/JENA, model Jenalumar 30G 0050) with filters for incident light (G-410) and for transmitted light (U-204 + 2 x K-425 + B422 or $2 \times \mathrm{KP}-560+\mathrm{G}-247)$. The number of pollen tubes that fluoresced bright blue against a dark blue background were subjectively assigned to three classes: "none" (no pollen tubes observed), "+" (less than 15 tubes), "++" (16-30 tubes), and "+++" (more than 30 tubes). Pollen grains were considered to have germinated when the pollen tube was longer than the diameter of the pollen grain. During the observations, abnormalities characteristic of incompatibility, such as deposition of callose on the walls of cells of stigmatic branches that had been in contact with pollen, or inhibition of pollen tube growth, were seen and noted (Knox and Williams, 1986).

\section{RESULTS}

The frequencies of sepal splitting were similar for the plants at both locations studied (Fig. 2a and 2b). Sepals began to split at 14:00 h (around 15\% of the flower buds). Ruptures began at any point along the natural seams between sepals and reached their highest frequency at 22:00 $\mathrm{h}$ (around $50 \%$ of flower buds). Anthesis occurred between 2:00 and 6:00 $\mathrm{h}$ on the following day. At 6:00 h, all the flowers were completely open, although some at CEPLAC (2.5\%) were still splitting their sepals. At EMBRAPA - Amazônia Oriental, at the same time, $40 \%$ of flowers were still splitting their sepals (Fig. $2 b$ ). While some variation could be observed, the highest frequency of anthesis occurred at dawn. At both sites flower abscission occurred from 14:00 h on anthesis day, continuing thereafter. At CEPLAC, the highest frequency of abscission occurred at 22:00 $\mathrm{h}$ on the day following anthesis $(17.3 \%)$ (the 06:00 h data were summed with the data from 2:00 $\mathrm{h}$, but even taking half of this figure, these data still contained the highest proportion of abscission). At EMBRAPA - Amazônia Oriental, abscission was at 6:00 h, i.e., $16 \mathrm{~h}$ before CEPLAC, where abscission was later and more scattered, which was possibly a populational characteristic. At CEPLAC, more grains of pollen reached the flowers than at EMBRAPA - Amazônia Oriental, but this seemed to have had no influence on setting fruit, because no fecundated flowers remained on the trees at CEPLAC. The majority of flowers remained opened on those trees for $24 \mathrm{~h}$. 

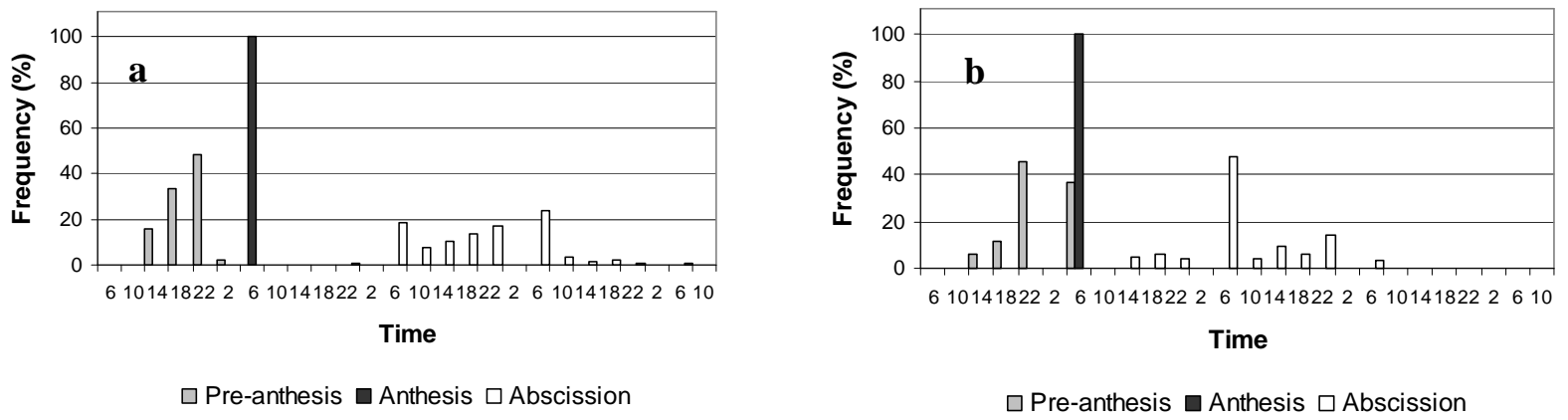

Figure 2 - Frequency of flowers by phases in the flower behaviour of cacauhy (T. speciosum): a) at CEPLAC/ERJOH in Marituba, PA. $\mathrm{N}=160$; b) at EMBRAPA - Amazônia Oriental N= 84. At 2 o'clock no observations were made.

With relation to the position of floral whorls, three basic configurations were observed and named as phase 1, 2 and 3. In "phase 1", there was little space between the floral whorls; some sepals were still joined in pairs and with staminodes slightly parallel to the peduncle longitudinal axis. The ligules and sepals had internal angles from $30^{\circ}$ to $45^{\circ}$. This configuration was typical of recently opened flowers, but it was observed that sometimes flowers that were close to abscission returned to this configuration. In recently opened flowers and in flowers close to abscission, the staminodes' apexes sometimes curved towards the centre. When flowers were in "phase 2", ligules and staminodes diverged more, with an internal angle of $45^{\circ}$ to $60^{\circ}$. This is the transition between phase " 1 " and phase "3". In "phase 3", ligules were close to the horizontal plane and staminodes reached their maximum aperture (internal angle of around $60^{\circ}$ ).
This was the mature flower configuration that persists for the longest proportion of the flower's life (Fig. 3). The exudate appeared soon after the anthesis, reaching its maximum between 6:00 to 10:00 $\mathrm{h}$ on the morning of anthesis and then reducing, but maintaining a cyclic variation for the following two days, always with peaking between 6:00 and 10:00 h (Fig. 4). Peroxidase enzyme activity was strong in the majority of flowers during the three days that they remained on the trees, although it was highest on the first day of anthesis (Fig. 4). A close relationship between the presence of exudate and Peroxidase activity suggested that the period that flowers are most receptive is between 6:00 and 10:00 $\mathrm{h}$ of the first day of anthesis (Fig. 4). Notwithstanding, fertilization was possible during the days that followed, particularly in the early morning.

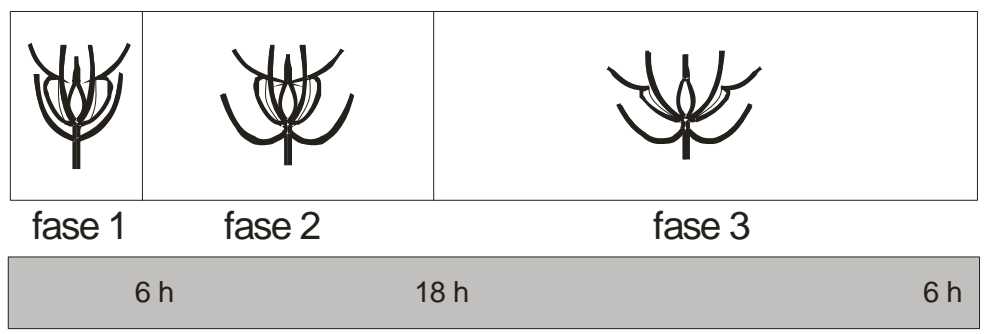

Figure 3 - Floral whorls position of cacauhy. Drawings made from the modes of grouped data from CEPLAC/ERJOH in Marituba, PA (N=160) and EMBRAPA - Amazônia Oriental (N= 84). 


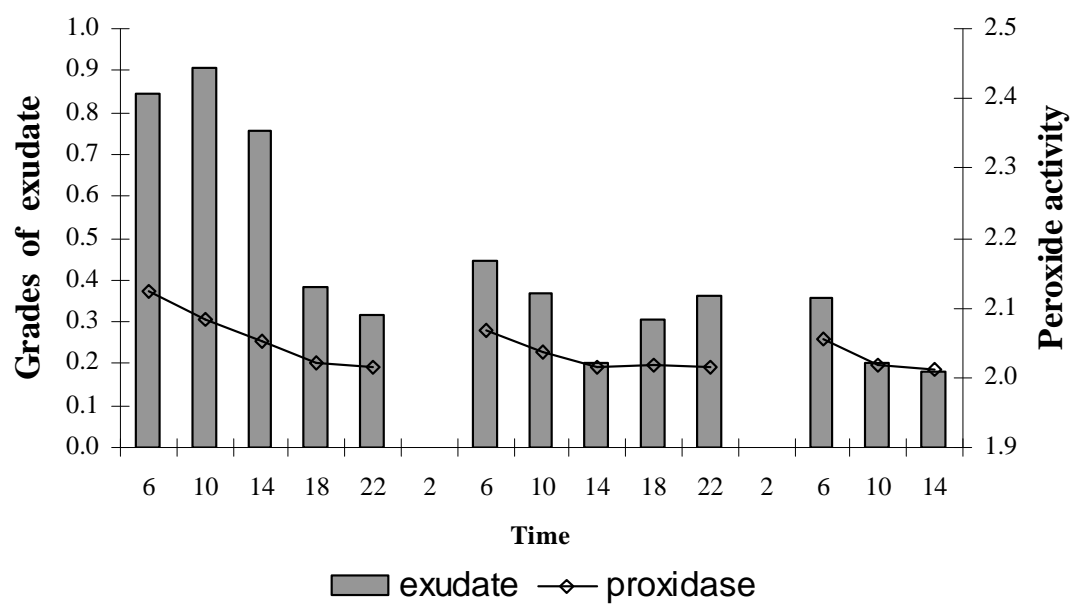

Figure 4 - Averages of grades attributed to the volume of exudation and Hydrogen Peroxide activity on stigmatic branches of cacauhy flowers $(\mathrm{N}=425)$. Grades correspond to the average of the number of styles observed by time. At 2 no observations were made.

The colours of the flower whorls and times of observation are given in Table 1. At the times assigned, flowers parts exhibited colours ranging from violet to ruby. From this point on, they became progressively browner. Sepal colours changed fast and demonstrated a good correlation with receptivity and as such were an appropriate indicator of flower receptivity. For the plants studied, the floral whorls with most intense odour were ligules and cogules, followed by staminodes and stamens, (Table 2). The group consisting of sepals, ovaries and peduncles showed the lowest odour levels.

Table 1 - Colours of the flower parts of cacauhy (Theobroma speciosum), from opening to fall, taken from the plant 6L-07 at CEPLAC/ERJOH, Marituba PA, Brazil.

\begin{tabular}{|c|c|c|c|c|}
\hline \multirow{2}{*}{ Time } & \multicolumn{4}{|c|}{ Flower Parts } \\
\hline & Sepal & Ligule & Petal Hood & Staminode \\
\hline $6: 00$ & $\begin{array}{l}\text { The internal surface is violet } \\
\text { brown }(11-8 \mathrm{E}) \text {. Externally, a } \\
\text { dark ruby }(12-7 \mathrm{~F})\end{array}$ & $\begin{array}{l}\text { Violet brown (11- } \\
8 \mathrm{~F})\end{array}$ & $\begin{array}{l}\text { Background pale red (11- } \\
\text { 3A) with brownish violet } \\
(11-8 D) \text { lines at the base }\end{array}$ & Violet brown $(11-7 \mathrm{~F})$ \\
\hline $10: 00$ & $\begin{array}{l}\text { Internally ruby (12-8D) and } \\
\text { externally dark ruby (12-8E) }\end{array}$ & $\begin{array}{l}\text { Ruby darker than } \\
\text { on sepals }(12-8 \mathrm{~F})\end{array}$ & $\begin{array}{l}\text { Background pastel red } \\
(10-4 \mathrm{~A}) \text { at base dark red } \\
(11-8 \mathrm{C}) \text { lines }\end{array}$ & Magenta (13-8F) \\
\hline $14: 00$ & $\begin{array}{l}\text { Internally violet brown }(11-8 \mathrm{E}) \\
\text { and externally dark ruby }(12- \\
8 \mathrm{~F})\end{array}$ & As before & $\begin{array}{l}\text { As before with a brownish } \\
\text { violet }(10-7 \mathrm{~F}) \text { base }\end{array}$ & As before \\
\hline 18:00 & $\begin{array}{l}\text { Internally and externally dark } \\
\text { ruby }(12-8 \mathrm{~F}) \text { with apex dark } \\
\text { purple }(14-7 \mathrm{~F})\end{array}$ & As before & As before & Dark ruby (12-7F) \\
\hline $22: 00$ & As before & As before & As before & As before \\
\hline $6: 00$ & As before & As before & As before & $\begin{array}{l}\text { As before but darker } \\
(12-8 \mathrm{~F})\end{array}$ \\
\hline $\begin{array}{l}\text { fallen } \\
\text { flower }\end{array}$ & Dark violet $(16-7 \mathrm{~F})$ & Violet $(15-7 F)$ & $\begin{array}{l}\text { Internally and externally } \\
\text { dark violet brown }(10-8 \mathrm{E})\end{array}$ & Dark violet (15-8F) \\
\hline
\end{tabular}


Table 2 - Odour of the flower parts of cacauhy (T. speciosum) at CEPLAC/ERJOH, in Marituba, PA, Brazil. Differences in odour by flower part are highly significant according to chi-square test $(\mathrm{p}<0.001), \mathrm{N}=81$.

\begin{tabular}{lcccc}
\hline \multirow{2}{*}{ Flower part classes } & \multicolumn{3}{c}{ Grades ${ }^{*}$} \\
\cline { 2 - 5 } & $\mathbf{1}$ & $\mathbf{2}$ & $\mathbf{3}$ & Means \\
\hline Ligule and petal hood & $0.0 \%$ & $2.8 \%$ & $97.2 \%$ & 2.97 \\
Staminode and stamen & $19.4 \%$ & $69.5 \%$ & $11.1 \%$ & 1.91 \\
Sepal, ovary and peduncle & $44.4 \%$ & $52.8 \%$ & $2.8 \%$ & 1.58 \\
\hline
\end{tabular}

*Grades subjectively attributed were: $1=$ odour perceptible with insistence; $2=$ odour moderately perceptible; $3=$ intense odour immediately perceptible.

The distribution of pollen grains by the position on stigmatic branches is illustrated in Figure 5. There was no significant difference between the naturally pollinated and unpollinated flowers in terms of the time that flowers remained on trees (based on the $t$ test, where $p=0.95$ and $\mathrm{DF}=230$ ) and there was also no association between the quantity of pollen deposited and the time that flowers remained on the tree (Pearson's coefficient, where $r=0.26$ and $\mathrm{N}=$ 152). For these tests, data from the two flowers that set fruit were excluded. No fruits resulted from selfpollination (45 flowers from three trees). Out- crossing resulted in 135 flowers being pollinated, 50 of which produced fruit (Table 3). The trees observed exhibited variations in their capacity to set the fruit. Some were mainly compatible $(\mathrm{B} \times \mathrm{C})$, and the others partially compatible $(\mathrm{A} \times \mathrm{B}, \mathrm{B} \times \mathrm{A}, \mathrm{C} \times$ B). Reciprocal crosses were similar in terms of fruit setting. The majority of the fruits recorded soon after the pollination became ripe $(76 \%)$. Pollen tubes grew both in self-pollinated (incompatible) and cross-pollinated (compatible) flowers. In both cases, pollen tubes reached the ovules and no abnormalities could be observed (Tables 4 and 5).

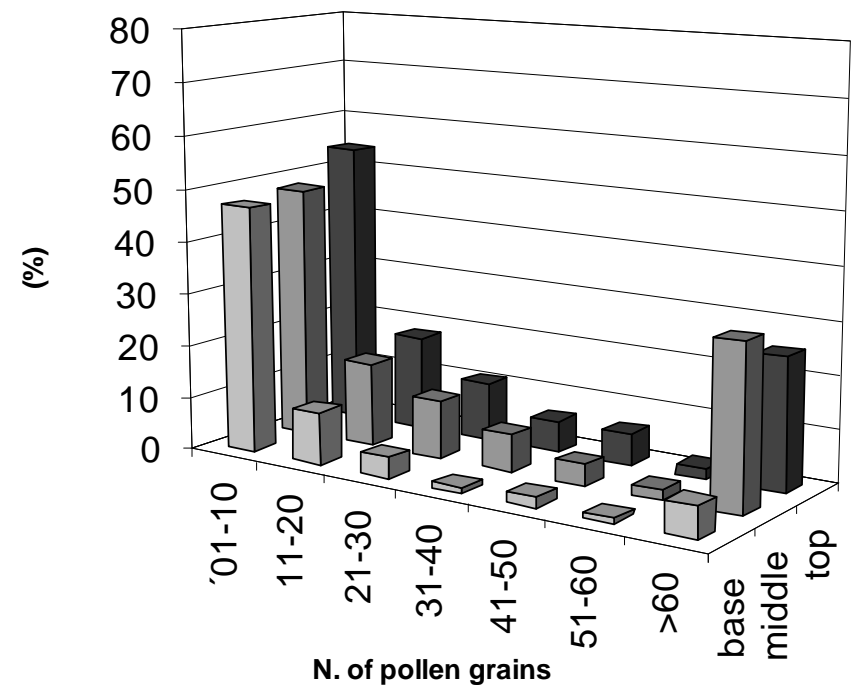

Figure 5 - Distribution of pollen grains by position on the stigmatic branches of cacauhy ( $T$. speciosum). Grouped data from CEPLAC/ ERJOH in Marituba, PA $(\mathrm{N}=160)$ and EMBRAPA - Amazônia Oriental (N=84). 
Table 3 - Fruit set under controlled pollination. Date of: a) 3 days after polination, b) 6 days after pollination; c) 9 days after pollination; d) 60 days after pollination (when ripe). $-=$ aborted flower; $+=$ healthy fruit; $*=$ aborted fruit. a)

\begin{tabular}{|c|c|c|c|}
\hline & $\mathbf{A}$ & B & $\mathbf{C}$ \\
\hline $\mathbf{A}$ & 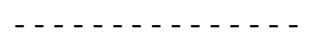 & +++++++------ & $++++++++--\cdots$ \\
\hline B & +++++++------ & $--\ldots-\ldots$ & +++++++----- \\
\hline $\mathbf{C}$ & ++++++++------ & +++++++++++++-- & 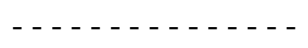 \\
\hline Control & $\ldots-\ldots \ldots$ & $-\ldots-\ldots-\ldots-\ldots$ & $-\ldots-\ldots-\ldots$ \\
\hline \multicolumn{4}{|l|}{ b) } \\
\hline & A & B & $\mathbf{C}$ \\
\hline $\mathbf{A}$ & - - - - - - - - - - & $+++++* * \ldots$ & $+++++++* \ldots$ \\
\hline $\mathbf{B}$ & $++++* * * \ldots$ & - - - - - - - - - - - & +++++++----- \\
\hline $\mathbf{C}$ & +++++++++----- & $++++++++++++*--$ & $\ldots$ \\
\hline Control & $-\ldots-\ldots-\ldots-\ldots$ & $-\ldots-\ldots-\ldots-\ldots$ & $-\ldots-\ldots-\ldots$ \\
\hline
\end{tabular}

c)

\begin{tabular}{|c|c|c|c|}
\hline & A & B & C \\
\hline $\mathbf{A}$ & ----------- & $++++* * * \ldots$ & $+++++++*----$ \\
\hline B & $++++* * * \ldots$ & $-\ldots$ & $+++++* * \ldots$ \\
\hline $\mathbf{C}$ & $++++++++---\ldots$ & $+++++++++* * \ldots$ & $-\ldots$ \\
\hline Control & - - - - - - - - - - & - - - - - - - - - - & $-\ldots$ \\
\hline
\end{tabular}

d)

\section{$\mathbf{A}$}

B

C

\begin{tabular}{|c|c|c|c|}
\hline $\mathbf{A}$ & 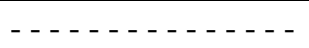 & $++++* * * \ldots$ & $++++++*{ }^{*}-$ - $_{-}$ \\
\hline B & $++++* * * \ldots$ & 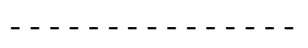 & $+++++* * \ldots$ \\
\hline $\mathbf{C}$ & $++++++* \ldots$ & $++++++++++* * * \ldots$ & - - - - - - - - - - - - \\
\hline Control & $-\ldots-\ldots-\ldots-\ldots$ & 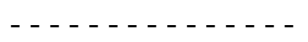 & 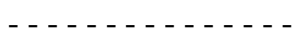 \\
\hline
\end{tabular}

Table 4 - Receptivity of stigma assessed by germination of pollen grains. The number of pollen tubes on stigmatic branches were estimated subjectively; +++= more than 30 tubes; ++=16-30 tubes; $+=$ less than 15 tubes; none $=$ no pollen tubes observed. At CEPLAC/ERJOH, Marituba, Brazil, 1995-1996.

\begin{tabular}{|c|c|c|c|c|c|c|c|c|c|c|}
\hline \multirow{2}{*}{$\begin{array}{l}\text { Pollination } \\
\text { time }\end{array}$} & \multicolumn{3}{|c|}{$+6 \mathbf{L - 0 7}$} & \multicolumn{2}{|c|}{ 6L-11 } & \multicolumn{4}{|c|}{$+6 \mathbf{L - 1 3}$} & \multirow{2}{*}{$\begin{array}{l}+6 \mathrm{~L}-16 \\
6 \mathrm{~L}-11\end{array}$} \\
\hline & $\mathbf{N}$ & 6L-07 & 6L-13 & $6 \mathrm{~L}-11$ & $6 \mathrm{~L}-16$ & $6 \mathrm{~L}-13$ & 6L-07 & $6 \mathrm{~L}-09$ & 6L-11 & \\
\hline \multirow[t]{5}{*}{ 7:00 } & 01 & none & + & & & none & + & none & & \\
\hline & 02 & none & + & & & none & + & + & & \\
\hline & 03 & + & ++ & & & + & + & ++ & & \\
\hline & 04 & ++ & ++ & & & +++ & ++ & +++ & & \\
\hline & 05 & +++ & +++ & & & +++ & +++ & +++ & & \\
\hline 10:00 & 01 & & & & +++ & +++ & & & +++ & +++ \\
\hline $14: 00$ & 01 & & & + & +++ & +++ & & & +++ & \\
\hline
\end{tabular}


Table 5 - Receptivity of stigma assessed by germination of pollen grains. The number of pollen tubes on stigmatic branches were subjectively estimated; $+++=$ more than 30 tubes; $++=16-30$ tubes; $+=$ less than 15 tubes; none $=$ no pollen tubes observed. At EMBRAPA - Amazônia Oriental, Belém, Brazil, 1996.

\begin{tabular}{|c|c|c|c|c|c|c|}
\hline \multirow{2}{*}{ Pollination time } & \multicolumn{4}{|c|}{$q_{+}$} & \multicolumn{2}{|l|}{${ }_{+} \mathbf{F}$} \\
\hline & $\mathbf{N}$ & $\delta^{\prime} \mathbf{E}$ & $\gamma \mathbf{G}$ & $\delta^{\prime} \mathbf{E}$ & $\delta^{\lambda} \mathbf{F}$ & $\lambda \mathbf{G}$ \\
\hline \multirow[t]{10}{*}{$7: 00$} & 01 & +++ & ++ & +++ & + & + \\
\hline & 02 & ++ & & + & +++ & +++ \\
\hline & 03 & +++ & & + & +++ & none \\
\hline & 04 & & & ++ & + & + \\
\hline & 05 & & & ++ & & + \\
\hline & 06 & & & + & & + \\
\hline & 07 & & & + & & + \\
\hline & 08 & & & ++ & & + \\
\hline & 09 & & & & & ++ \\
\hline & 10 & & & & & + \\
\hline
\end{tabular}

\section{DISCUSSION}

In the present work, the flower buds split their sepals between 14:00 and 6:00 h. At 6:00 h, almost all of the flowers were fully open. In Costa Rica, Young et al. (1987) observed that cacauhy flowers split their sepals (equivalent to the pre-anthesis phase) at 15:00 $\mathrm{h}$ and began to open (equivalent to phase 1) at 20:00 h) and were not fully open by 9:00 h, although between 8:00 and 11:00 h, mature flowers (phase 2 to 3 ) were present. Thus, there was some agreement between the two studies here, considering that small variations were acceptable, due to environmental or even genetic variability.

The same sequence of odour levels observed for cacauhy whorls has also been described of cupuassu (T. grandiflorum) (Venturieri, 1994), of cacaucabeça-de-urubu ( $T$. obovatum) (Souza and Venturieri, 1998) and of cupuí (T. subincanum) (Rodrigues and Venturieri, 1997). In the case of cupuassu, the cogules appeared to function as a dumb waiter for fallen pollen grains, from where insect pollinators collected them (Venturieri, 1994). It has also been suggested that this is a sheltered place for Chrysomelidae weevils, which use it for mating and so promote pollination (Venturieri et al., 1997). Rodrigues-Silva (2003) considered that the flies of the group Bromeliae (Drosophilidae), and some species of Phoridae, were the effective pollinators of cacauhy. These insects arrive on the ligules, passing to the petal hoods, where they come into contact with the anthers with pollen grains and then go to the base of the ovary, scraping their backs against the stigmatic branches on the way. These pollinators were observed feeding at the base petal hoods. The insects that Rodrigues-Silva (2003) considered to be effective pollinators were abundant at the time that the present study indicated flowers were most receptive. When flower whorls were in the phase 2 position (Fig. 3), the arrival of pollinators was facilitated and they were forced to distribute the pollen grains to the stigmatic branches as described above. The floral whorls with most intense odour were the ligules and cogules, followed by staminodes and stamens, reinforcing the hypothesis that they were attracting pollinators.

Although the Peroxidase reaction showed that cacauhy flowers remained receptive throughout the whole time the flowers were on the trees (2-3 days), these results could be debatable. Venturieri (1994) mentioned that senile stigmas of cupuassu ( $T$. grandiflorum) reacted to $\mathrm{H}_{2} \mathrm{O}_{2}$ due to an increase in tissue permeability and so the unexpectedly high levels of $\mathrm{H}_{2} \mathrm{O}_{2}$ reaction to pistils on the days following anthesis could be an experimental artefact, because the results of pollen tube growth in pollinated flowers with compatible and incompatible pollen (see Tables 4 and 5) meant that cacauhy's stigmatic branches were receptive throughout the morning and early afternoon of the day of anthesis. Nevertheless, the Peroxidase reaction was positive all along the stigmatic branches, suggesting that pistils were receptive throughout their length, as has been observed of ( $T$. grandiflorum) (Venturieri, 1994), cacau-cabeça-de-urubu (T. obovatum) (Souza and Venturieri, 1998) and cupuí (T. subincanum) (Rodrigues and Venturieri, 1997).

In the present study, $65.5 \%$ of the cacauhy flowers were naturally pollinated $(\mathrm{N}=234)$. This pollination level was quite high when compared with other 
species of the genus, such as: $T$. grandiflorum (1.6 \%) (Venturieri, 1994), T. cacao (2 - $4 \%$ ) (Free, 1993; Parvais et al., 1977), T. obovatum (7.5\%) (Souza and Venturieri, 1998) and T. subincanum (18.7\%) (Rodrigues and Venturieri, 1997), but lower than Herrania mariae, in which $100 \%$ of the flowers were naturally pollinated (Venturieri and Silva, 1997).

In cupuassu ( $T$. grandiflorum), hand pollination between compatible plants showed that $20 \%$ of flowers that received 60 pollen grains set a fruit, while flowers that received more than 400 pollen grains always set a fruit (Venturieri and RibeiroFilho, 1995). The cacauhy fruit had 20-26 seeds, less than cupuassu, which had 36 or even 50 (Cuatrecasas, 1964, Venturieri, 1993), so it was possible that less pollen would be necessary for a cacauhy flower to set a fruit than for a cupuassu flower. In cacauhy, only two of the naturally pollinated flowers set a fruit: one had a pistil with 59 pollen grains and another with 120 , so, potentially, more of the naturally pollinated flowers would have received enough pollen to set fruit, but only $0.85 \%$ of them set a fruit, which was a sign that a significant number of flowers were pollinated with incompatible pollen. In the controlled pollination experiment with cacauhy, the majority of flowers that had set a fruit, when evaluated on the 3rd day after pollination, remained on the tree on the 60th day. Considering that the majority of aborted fruit were damaged by the insects, it could be concluded that any incompatibility reactions had already occurred before the 3rd day of pollination. The following three observations suggested that the incompatibility system in cacauhy was under gametophytic control, occurring inside the ovules, as has been observed in cocoa (T. cacao) (Cope, 1962) and cupuassu (T. grandiflorum) (Venturieri, 1994): a) pollen tubes growing both in cross-pollinated (compatible) and self-pollinated (incompatible) flowers, b) reciprocal crosses that were similar in their fruit set and c) the site of incompatibility.

The aim of the present study was to produce a theoretical basis for the search for opportunities to hybridise cacauhy ( $T$. speciosum) with other Theobroma species. Although cacauhy begin to split their sepals at 14:00 h, they were fully open between 2:00 and 6:00 $\mathrm{h}$ the following morning. The flowers of cacau-cabeça-de-urubu $(T$. obovatum) usually opened between 22:00 to $6: 00 \mathrm{~h}$ with the highest deposition of pollen grains on the upper third of the stigmatic branches and there was indirect evidence that the period of receptivity was most intense between anthesis and 18:00 $\mathrm{h}$ of the same day (Souza and Venturieri, 1998). Cupuassu flowers ( $T$. grandiflorum) begin to split their sepals at any time of the day, but anthesis occurred between 16:00 and 18:00 $\mathrm{h}$ with the natural deposition of pollen grains occurring at any part of the stigmatic branches and with a period of highest receptivity from anthesis up to $10: 00 \mathrm{~h}$ on the following day (Venturieri, 1994). Cocoa (T. cacao), flowers began anthesis during late afternoon and anthesis was complete at dawn of the following day (Free, 1993) with the period that they were most receptive being between 10:00 $\mathrm{h}$ of the day of anthesis and 13:00 $\mathrm{h}$ of the following day (Sampayan, 1966). In cupuí (T. subincanum), sepal splitting and anthesis were almost simultaneous and occurred mainly between 2:00 and 6:00 $\mathrm{h}$ with the period that they were most receptive being between 10:00 $\mathrm{h}$ on the day of anthesis and 22:00 $\mathrm{h}$ on the following day (Rodrigues and Venturieri, 1997). Attempts to hybridise those species will, therefore, have to take into account the period of receptivity of the female parts and availability of pollen grains from the male parts.

Considering that the location where the highest frequency of natural deposition of pollen grains that should be the part with the most effective pollination, it could be suggested that for hand pollinations using cacauhy as a female, the pollen would preferably be deposited from the middle to the top third of the stigmatic branches.

\section{ACKNOWLEDGEMENTS}

We thank to the Conselho Nacional de Desenvolvimento Científico e Tecnológico Programa para o Tropico Úmido (proc. No. 63.00.13/95-0) and the International Foundation for Science (Grant no. D/2456-1) for the resources used in the present project. We also thank the Universidade Federal do Pará, Comissão Executiva do Plano da Lavoura Cacaueira, and Empresa Brasileira de Pesquisa Agropecuária - Amazônia Oriental (EMBRAPA - Amazônia Oriental), for providing laboratory and field facilities, and to Edilson de F. Leal, Alessandra de A. Rodrigues, Simony S. P. de Souza, Marivana B. Silva, Antônio E. da Rocha, for the extraordinary help during the development of the present work. 


\section{RESUMO}

Neste trabalho foi estudada a biologia floral do cacaui (Theobroma speciosum). Os botões florais romperam a suas sépalas às $14 \mathrm{~h}$ com a maior frequiência às $22 \mathrm{~h}$, estando completamente abertas às $6 \mathrm{~h}$ da manhã seguinte. Os braços estigmáticos apresentaram exsudato, com o nível máximo entre 06 e 10 horas da manhã do mesmo dia. As lígulas mais as cógulas foram as partes florais com odor mais intenso. As flores estavam receptivas durante toda a manhã e à tarde do dia da antese. Aproximadamente $65 \%$ das flores foram naturalmente polinizadas, mas somente $0,85 \%$ formou fruto. A abscisão ocorreu com maior frequência às $6 \mathrm{~h}$ do segundo dia após a antese. Polinizações controladas mostraram que o cacauí é uma espécie auto- incompatível.

\section{REFERENCES}

Addison, G. and Tavares, R. (1952), Hybridisation and grafting in species of Theobroma which occur in Amazonian. Evolution., 6, 380-386

Cavalcante, P.B. (1988), Frutas comestiveis da Amazônia, $4^{\underline{a}}$ ed., Museu Paraense E. Goeldi/Souza Cruz, Belém, 279 p

Cope, F.W. (1962), The mechanism of pollen incompatibility in Theobroma. Heredity.,17, 157-182

Cuatrecasas, J. (1964), Cacao and its allies: a taxonomic revision of the genus Theobroma. Contr. U. S. Nat. Herb., 35, 379-614

Ducke, A. (1953), As espécies brasileiras do gênero Theobroma L Boletim Técnico do IAN $N^{o} 28$, Belém Pará Brasil

FAO, (1986). Food and Fruit-bearing Forest Species. 3. Examples from Latin América,: FAO Forestry Paper 44/3, Rome, pp. 147-158

Free, J.B. (1993), Insect pollination of crops. 2nd ed., Academic Press, London

Kho, Y.O. and Baer, J. (1986), Observing pollen tubes by means of fluorescence. Euphytica., 17, $298-302$

Knox, R.B. and Williams, E.G. (1986), Pollen, pistil, and reproductive function in crop plants. Plant Breeding Reviews., 4, 7-79

Kornerup, A. and Wanscher, H. (1984), Methuen Handbook of Colour,. Methuen London Ltd., London.

Le Cointe, P. (1934), Árvores e plantas úteis da Amazônia.Livraria Clássica, (Amazônia Brasileira, 3), Belém, pp. 145-46
Martinson, V.A. (1972), Embryological studies on hybridisation between Theobroma cacao and Theobroma grandiflorum. Canadian Journal of Botany., 50, 2117-2124

Neves, A.D. de S. and Barbosa, R.C.M. (1983), Levantamento detalhado dos solos do Campo de Introdução de Theobroma da Amazônia. (Boletim Técnico $\mathrm{n}^{\circ}$ 109). CEPLAC- Comissão Executiva do Plano da Lavoura Cacaueira, Ilhéus/Itabuna, p. 1-30

Parvais, L.P., Reffye, P.H. de; and Lucas, P. (1977), Observations sur la polinisation libre chez Theobroma cacao: analyse mathématique des données et modélisation. Café Cacao Thé., 21, 253-62

Radford, A.E., Dickison, W.C., Massey, J. R.. and Bell, C.R. (1974), Vascular Plant Systematics. Harper and Row Publishers, New York

Rodrigues, A. de A. and Venturieri, G.A. (1997), Floral biology of "cupuí" (Theobroma subincanum) Sterculiaceae. Anais do I Encontro de Botânica Econômica de Espécies Nativas da América Latina; CATI, 21 - 22 de agosto, Campinas/SP/Brasil

Rodrigues-Silva, A de A.(2003), Polinização de cacauí (Theobroma speciosum Willd. ex Spreng. Sterculiaceae): implicações para conservação. Dissertação de Mestrado, Universidade Federal do Pará - UFPA / Museu Paraense Emílio Goeldi MPEG, Belém, Brasil

Salati, E. (1985), The climatology and hydrology of Amazonia, In - Key Environments- Amazonia, ed. G.T. Prance and T.E. Lovejoy, Pergamon Press, Oxford, pp. $18-48$

Sampayan, T.S. (1966), Flower biology, fruiting habit and compatibility relationship in cacao. Philippine Journal of Plant Industry.,31, 193-201

Souza, S.P. de and Venturieri, G.A. (1998), Floral phenology of cacau-cabeça-de-urubu (Theobroma obovatum). In-Venturieri, GA. Biologia aplicada à domesticação de fruteiras amazônicas do gênero Theobroma - Primeiro relatório: $\mathrm{CNPq} /$ Programa de Trópico Úmido - PUT/Proc. n. 63.00.13/95. 105 p. Belém, PA, Brasil

Venturieri, G.A. and Ribeiro-Filho, A.A. (1995), A polinização manual no cupuaçuzeiro (Theobroma grandiflorum (Willdenow ex Sprengel) Schumann). Acta Amazônica.., 25, 181-192

Venturieri, G.A. and Silva, M.B.(1997), Fenologia floral do cacau-jacaré (Herrania mariae)- Sterculiaceae. Boletim do Museu Paraense Emílio Goeldi, série botânica., 13, 31-47

Venturieri, G.A. (1993), Cupuassu: a espécie, sua cultura, usos, e processamento, Clube do Cupu, Belém

Venturieri, G.A. (1994), Floral Biology of Cupuassu (Theobroma grandiflorum (Willdenow ex Sprengel) Schumann), PhD Thesis, Univ. of Reading, UK 
Venturieri, G.C., Maués, M.M. and Miyanaga, R. (1997), Polinização do cupuaçuzeiro (Theobroma grandiflorum, Sterculiaceae): um caso de cantarofilia em uma fruteira amazônica. (Anais do Seminário Internacional Sobre Pimenta-do-reino e Cupuaçu, Belém, PA). Documentos Embrapa Amazônia Oriental/JICA vol. 89, p. 341-350

Young, A.M., Erickson-Jr., E.H., Strand, M. and Erickson, B. (1987), Pollination biology of Theobroma and Herrania (Sterculiaceae) - I. Floral biology. Insect Science and its Application., 8, 151-164
Zeisler, M. (1938), Über die abgrenzung der eigenthchen narbenfläche mit hilfe von reaktionen. Beihefte Botaniska Zentralblatt (A)., 58, 308-318

Received: March 25, 2007; Revised: November 05, 2008; Accepted: October 01, 2009. 